\title{
2 相混合体理論からみた有効応力の定義について
}

ON THE DEFINITION OF EFFECTIVE STRESS

BY THE THEORY OF 2-PHASE MIXTURE,

岡

$$
\begin{gathered}
\text { 三 三 生* } \\
\text { By Fusao ()KA }
\end{gathered}
$$

\section{1. まえがき}

Terzaghi ${ }^{1), 2)}$ によって明確に意識され，提案された， 有効応力の概念は，土質力学の分野において中心的な役 割を果たしており，経験的に有用な概念であることが知 られている. しかしながら，その物理的意味の検討は， 十分であるといいがたいのが現状である. Terzaghi は 有効応力の原理を飽和土に関する, 圧縮性と強度に関す る実験データを基礎に, 提案した. その後, Rendulic ${ }^{3)}$ らを始めとする, 間隚水圧の測定を基礎として, その有 用性が明らかにされ，さらに Bishop")や Skempton ${ }^{5)} に$ よって, 有効応力自体についての考察が行われてきた. それ以前の有効応力の概念の歴史については， Skempton $^{6)}$ によって詳しくまとめられている. 今日における 有効応力についての説明は，そのほとんどすべてが Bishop とSkempton によって行われた検討によるとい っても過言ではない. Terzaghi は有効応力を使用して, 1 次元圧密理論を導いたが，現在では，Biot による 2 相混合体理論を使用する多次元圧密問題 ${ }^{2}$ や混合体理論 を使った液状化解析五が取り上げられている.

いいかえれば， 2 相系の混合体としての取扱いは，便 宜的なものではなく, 飽和土の運動を解析するうえで, 本質的なものであるといえる. したがって，2 相混合体 の理論9 (11) と有効応力の概念の関係を明らかにしてお

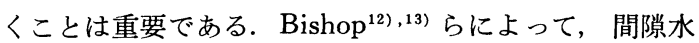
圧係数については, 独自の立場から調べられているが, 有効応力と混合体理論の関係は不十分である. 本論の目 的は, Terzaghi の有効応力の意味を 2 相混合体理論に より明らかにし, より正確な定義を与え, その適用範囲 を明らかにすることにある. 現在行われている有効応力 の説明は, 土粒子接触面積を考慮した, 力のつり合いを 中心に行われてきたが, 本論では変形の面からも考察を
行った. 圧密現象においては土中の水が排水されない限 り土の圧縮変形は進行しない.これは等方的応力が作用 した場合, 飽和土の変形は水の運動に依存しているこ と，いいかえれば，間隚水は土粒子骨格の運動の自由を 制限している．つまり，圧縮性の低い間隚水が土の運動 を拘束していることになる (以後, 拘束という言葉をこ の意味で使うことにする). ここではこの点に着目し, ミクロな粒子構造を問題にすることなく, 有効応力の定 義を行った.

\section{2 相混合体の構成式と有効応力の定義}

2 相混合体の理論としては， Biot $^{10)}$ をはじめとして， Green \& Naghdi ${ }^{14)}$ や Müller ${ }^{15}$ によって一般化された 理論が存在する. 著者はすでに, Green \& Naghdi の 理論による全応力の定義に基づいて, 飽和粘性土の構成 理論を導いている9 . そこでは，土粒子々間郘水の圧縮 性を考慮した場合, 固体相と流体相の間に相互作用が発 生することを指摘した. ここでは，土粒子（固体相を構 成する物体）の圧縮性と間嚐水の圧縮性を考虑するが, 相互作用は圧縮変形に対してのみあると仮定する. その 理由は, 実際に飽和土において, 間淂水が固体相の運動 の自由を制限するのは, 圧縮変形に対してだけとみなし 得るからである. したがって以下の解析では, 応力ーひ ずみ関係として，圧縮変形に対するものだけを取り上げ る.

固体と流体からなる 2 相混合体理論においては，混合 体を固体相と流体相という抽象的な 2 つの連続体として の相の重效合せで表現する. 固体相は, 物理的には土粒 子で構成される土粒子骨格を表す連続体を示しており, 流体相は間隙水から構成される連続体を示している.

図一1 は，相の重ね合せを示す模式図である，以上述 べた 2 つの相が抽象的であるという理由は, 図一1に示 すような密度が $(1-n) \rho^{(s)}, n \rho^{(f)}$ の連続体は現実には 
Saturated Soil Solid Phase Fluid Phase

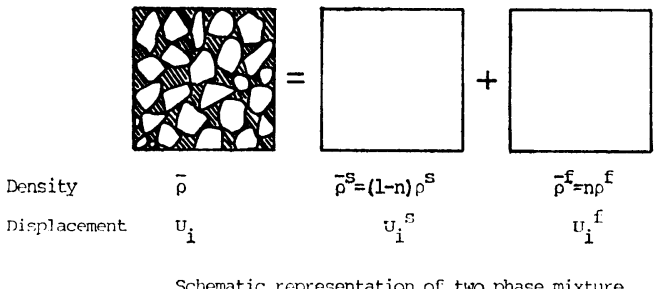

図一1 2 相混合体の模式図

存在しないが，現実の土を 2 つの相に写像し，その重ね 合せとして，土の挙動を表現するからである．図一1で $U_{i}^{(s)}, U_{i}^{(f)}$ は，それぞれの相の変位べクトルである が，これらの量は実際の土からみれば，平均的な量とな っている.

自由エネルギー密度を $\psi^{(s)}$ (固体相に対して)， $\psi^{(f)}$ （流体相に対して）とおくと, 応カテンソルは次式より 求めることができる91.

$$
\begin{aligned}
\sigma_{i j}{ }^{(s)} & =\bar{\rho}_{o}{ }^{(s)} \frac{\partial \psi^{(s)}}{\partial \varepsilon_{i j}{ }^{(s)}} \cdots \\
\sigma_{i j}{ }^{(f)} & =\bar{\rho}_{o}{ }^{(f)} \frac{\partial \psi^{(f)}}{\partial \varepsilon_{i j}{ }^{(f)}}
\end{aligned}
$$

$\sigma_{i j}{ }^{()}:$応力テンソル $(s, f$ はそれぞれ固体相, 流体相を示す指標である)

$\varepsilon_{i j}^{()}:$ひずみテンソル

$\bar{\rho}_{o}{ }^{()}$: 初期密度

次に, エネルギ一関数の具体的な形を式 (3) と式 (4) で与える. 以下すべて微小変形勾配を仮定する.

$$
\begin{aligned}
& \bar{\rho}_{o}{ }^{(s)} \psi^{(s)}=\frac{1}{2} \gamma_{1} \varepsilon_{i j}{ }^{(s)} \varepsilon_{i j}{ }^{(s)}+\frac{1}{3} \gamma_{2} \varepsilon_{K K^{(s)}} \varepsilon_{K K^{(f)}} \\
& \bar{\rho}_{o}^{(f)} \psi_{r}^{(f)}=\frac{1}{6} \gamma_{3} \varepsilon_{K K}{ }^{(f)} \varepsilon_{K K^{(f)}} \\
& +\frac{1}{3} r_{4} \varepsilon_{K K^{(f)}} \varepsilon_{K K^{(s)}}
\end{aligned}
$$

ただし, $r_{i}(i=1 \sim 4)$ は材料定数である.

$$
\text { 式 (1) （3) と式 (4)より, }
$$

$$
\sigma_{i j}{ }^{(s)}=r_{1} \varepsilon_{i j}{ }^{(s)}+\frac{1}{3} r_{2} \varepsilon_{K K^{(f)}} \delta_{i j}
$$

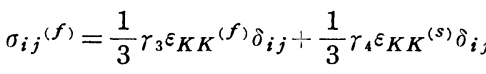

$\left(\delta_{i j}\right.$ はクロネッカーのデルタを示す)

等方成分についてのみ書き直すと,

$$
\begin{aligned}
& \sigma_{K} K^{(s)}=r_{1} \varepsilon_{K K^{(s)}}+r_{2} \varepsilon_{K} K^{(f)} \ldots \\
& \sigma_{K} K^{(f)}=r_{3} \varepsilon_{K} K^{(f)}+r_{4} \varepsilon_{K} K^{(s)} \ldots
\end{aligned}
$$

相互作用が 2 相間で等しいとすると， $r_{2}=r_{4}$ となる. $\sigma_{i j}{ }^{(s)}$ と $\sigma_{i j}{ }^{(f)}$ は混合体としての面上で定義される量で ある. 式 (7) で固体相の応力が 2 つの相のひずみに依 存する形をとっているのは，飽和土を考えた場合，完全
な排水条件以外では，固体相の応力が間嚐水の挙動にも 支配されるということであり，式（8）についても同様 のことが成立する.

以上のようにして求められた 2 相混合体の応力ーひず み関係は, Biot の線形理論に一致する. Biot の理論に 表れる応力ーひずみ関係の定数と土の物理定数との関係 は，すでに石原 ${ }^{16), 17)}$ が詳しく論じている. したがって 以下，石原による記号を用いることにする. 式 (7) と 式（8）を書き直すと,

$$
\begin{aligned}
& \sigma^{(s)}=\alpha_{b} \varepsilon_{K K^{(s)}}+\alpha_{c} \varepsilon_{K K^{(f)}} \\
& \sigma^{(f)}=\alpha_{c} \varepsilon_{K K^{(s)}+k_{c} \varepsilon_{K K^{(f)}}}
\end{aligned}
$$

ここで,

$$
\sigma^{(s)}=\frac{1}{3} \sigma_{K K^{(s)}}, \sigma^{(f)}=\frac{1}{3} \sigma_{K K^{(f)}}
$$

である. 式（9）と式（10) を解いて，ひずみで書き直 すと,

$$
\begin{aligned}
& \varepsilon_{K K^{(s)}}=\frac{1}{\alpha_{b} k_{c}-\alpha_{c}{ }^{2}}\left(k_{c} \sigma^{(s)}-\alpha_{c} \sigma^{(f)}\right) \\
& \varepsilon_{K K^{(f)}}=\frac{1}{\alpha_{b} k_{c}-\alpha_{c}{ }^{2}}\left(\alpha_{b} \sigma^{(f)}-\alpha_{c} \sigma^{(s)}\right) \\
& \left(\alpha_{b}, \alpha_{c}, k_{c}\right. \text { は材料定数である) }
\end{aligned}
$$

さらに， $\varepsilon_{K K^{(s)}} ， \varepsilon_{K K^{\prime}}{ }^{(f)}$ と土粒子実質部分の体積ひ ずみ $e_{s}$, 水の体積ひずみ $e_{w}$ と間嚐の体積ひずみ $e_{p}$ の 関係は,

$$
\begin{aligned}
& \varepsilon_{K K^{(s)}}=n e_{p}+(1-n) e_{s} \ldots \ldots \ldots \\
& \varepsilon_{K K^{(f)}}=e_{w}+(1-n)\left(e_{s}-e_{p}\right) \\
& n: \text { 間嚐率 }
\end{aligned}
$$

飽和土を非被覆の状態（つまり，メンブレーンなどを つけない状態）で水中におき，水圧 $u$ を作用させた場合 (石原 ${ }^{17)}$ はこのような試験を浸水試験とよんでいる),

$$
\varepsilon_{K K}{ }^{(s)}=e_{p}=e_{s}
$$

となり，

$$
\begin{aligned}
& e_{s}=c_{s} u, \\
& e_{w}=c_{l} u \\
& c_{s}=-\frac{(n-1) k_{c}+n \alpha_{c}}{\alpha_{b} k_{c}-\alpha_{c}{ }^{2}} \\
& c_{l}=\frac{(n-1) \alpha_{c}+n \alpha_{b}}{\alpha_{b} k_{c}-\alpha_{c}{ }^{2}}
\end{aligned}
$$

$c_{s}$ は, 土粒子実質部分の圧縮率， $c_{l}$ は，水の圧縮率で ある.

次に，排水試験を考える。 このとき， $\sigma_{k \boldsymbol{k}}(f)=0$ だか ら,

$$
\varepsilon_{K K^{(s)}}=\frac{k_{c}}{\alpha_{b} k_{c}-\alpha_{c}^{2}} \sigma^{(s)}=c_{b} \sigma^{(s)}
$$

$c_{b}$ は土粒子骨格の圧縮率である. さらにこのとき,

$$
\varepsilon_{K K}{ }^{(f)}=\frac{-\alpha_{c}}{\alpha_{b} k_{c}-\alpha_{c}{ }^{2}} \sigma^{(s)}
$$

$c_{p}$ を間隙の圧縮率であるとすると，式（13）と式 (14) から 
となるから，

$$
\varepsilon_{K K^{(s)}}=\varepsilon_{K K^{(f)}}+e_{p}
$$

$$
e_{p}=\frac{k_{c}+\alpha_{c}}{\alpha_{b} k_{c}-\alpha_{c}{ }^{2}} \sigma^{(s)}=c_{p} \sigma^{(s)}
$$

以上で, 混合体のパラメーターと土の力学定数が求め られた. したがって, 有効応力を定義する際に基本的で あると考えられる, 等方的外圧 $\sigma$ が非排水状態の飽和土 に作用したときの, 固相と流体相に対する応力の分配率 を求める. 非排水状態では $\varepsilon_{K} K^{(s)}=\varepsilon_{K} K^{(f)}$ だから, 式 (11) と式 (12) から,

$$
k_{c} \sigma^{(s)}-\alpha_{c} \sigma^{(f)}=-\alpha_{c} \sigma^{(s)}+\alpha_{b} \sigma^{(f)}
$$

$$
\sigma=\sigma^{(f)}+\sigma^{(s)} \text { だから, 式 (22) より, }
$$

$$
\sigma^{(f)}=\frac{\alpha_{c}+k_{c}}{k_{c}+2 \alpha_{c}+\alpha_{b}} \sigma .
$$

式 (17)，(18）と式（19）功式（23）を書き換える と,

$$
\sigma^{(f)}=\frac{c_{b}-c_{s}}{\frac{1}{n} c_{b}-\left(1+\frac{1}{n}\right) c_{s}+c_{e}} \sigma
$$

式 (24)より, 外圧 $\sigma$ が作用したとき, $\sigma^{(f)}$ は $c_{s}=$ 0 で, かつ $c_{l} / c_{b}=0$ のときに限り, $\sigma^{(f)}=n \sigma$ となる. 同時に, $\sigma^{(s)}$ は,

$$
\sigma^{(s)}=\frac{\left(\frac{1}{n}-1\right) c_{b}-\frac{1}{n} c_{s}+c_{l}}{\frac{1}{n} c_{b}-\left(1+\frac{1}{n}\right) c_{s}+c_{l}}
$$

式 (25) より, $c_{s}=0$ で $c_{l} / c_{b}=0$ のときには, $\sigma^{(s)}=$ $(1-n) \sigma$ となる. このように, 関係式 $\sigma^{(f)}=n \sigma, \sigma^{(s)}=$ $(1-n) \sigma$ は, 非圧縮性材料の場合に Biot が導いている 式に一致している. つまり，非圧縮性材料の場 合に限 り, 有効応カテンソルの定義として次式が成立する.

$$
\begin{aligned}
& \sigma_{i j}{ }^{e}=\sigma_{i j}{ }^{(s)}-(1-n) u^{\prime} \delta_{i j} \\
& \sigma_{i j}{ }^{(f)}=n u^{\prime} \delta_{i j}
\end{aligned}
$$

ただし，

$$
\sigma_{i j}=\sigma_{i j}{ }^{(s)}+\sigma_{i j}(f)
$$

$u^{\prime}$ は間嚐水圧である.

以上の考察から, 非排水状態で外圧 $\sigma\left(=\frac{1}{3} \sigma_{K K}\right)$ が 作用したときに固体相（土粒子骨格）と流体相（間隙水） が受けもつ応力の分配率は, 固相 構成物 質（土粒子自 身）の圧縮性，固体相（土粒子骨格）の圧縮性と間隙流 体の圧縮性によって決まる.

非排水試験と非被覆の浸水試験を 1 次元で模式的に説 明するために示したのが, 図一2 である. 混合体が $E_{1}$ と $E_{2}$ という 2 つ圧縮性の異なる材料でできていると する.

単位面積 (混合体としての) 当りに, 圧力 $P$ が加わ るとき, 非排水試験では変形の拘束 $\left(\varepsilon_{K K^{(s)}}{ }^{(s} \varepsilon_{K K^{(f)}}\right)$ があるため（図一2 では，この拘束を剛な平板で表して (る), 応力の分配は, $E_{1}$ と $E_{2}$ の違いにより,

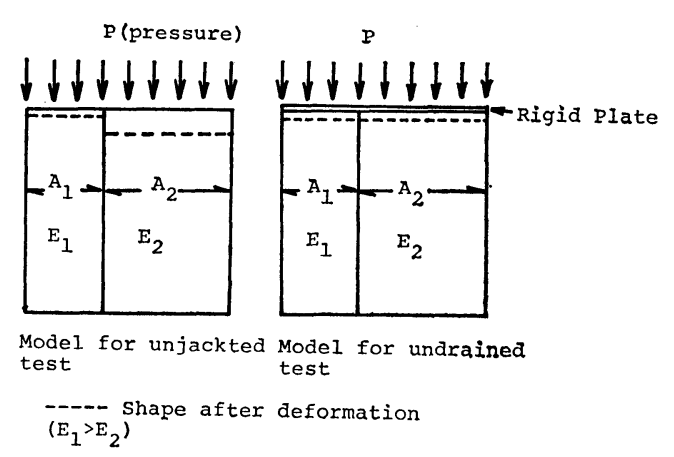

図一2 非排水試験と非被裖試験の模式図

$$
\begin{aligned}
& \bar{\sigma}_{1}=\frac{P\left(A_{1}+A_{2}\right)}{A_{1}+\frac{E_{2}}{E_{1}} A_{2}} . \\
& A=A_{1}+A_{2} \\
& \bar{\sigma}_{2}=\frac{P\left(A_{1}+A_{2}\right)}{\frac{E_{1}}{E_{2}} A_{1}+A_{2}} .
\end{aligned}
$$

$\bar{\sigma}_{1}, \bar{\sigma}_{2}$ : 断面積 $A_{1}, A_{2}$ 当りの応力である. したがっ て，2相混合体としてはそれぞれの相に，

$$
\begin{gathered}
\sigma_{1}=\frac{P}{A_{1}+\frac{E_{2}}{E_{1}} A_{2}} \\
\sigma_{2}=\frac{P}{\frac{E_{1}}{E_{2}} A_{1}+A_{2}}
\end{gathered}
$$

これに対して，非被覆試験では，

$$
\begin{aligned}
& \sigma_{1}=\frac{A_{1} P}{A} \\
& \sigma_{2}=\frac{A_{2} P}{A}
\end{aligned}
$$

となって, 応力の分配は, 混合体単位面積当りに占める 各相の面積の割合によって決まる，この $A_{1} / A$ を，間偗 率に相当するとすれば, $\sigma_{1}=n P, \sigma_{2}=(1-n) P$ となり， 式 (26) で表す関係が常に成り立つ.

次に, さらに進んで, 有効応力を定義する. ここでい う“有効”という意味は, 非排水状態で等方圧が作用し たときの変形が無視し得る場合, これ以外の変形を起こ し得る応力を有効応力とよぶということである.

非排水状態で等方圧 $\frac{1}{3} \sigma_{K K}(=\sigma)$ が作用したとき, 間隚内で観測される流体圧を $u^{\prime}$ とすると， $\sigma^{(f)}$ は次式 で与えられる.

$$
\sigma^{(f)}=n u^{\prime}
$$

したがって，固相に対しては， $\sigma^{(s)}=\sigma-\sigma^{(f)}$ より，

$$
\sigma^{(s)}=\frac{\left(\frac{1}{n}-1\right) c_{b}-\frac{1}{n} c_{s}+c_{l}}{c_{b}-c_{s}} n u^{\prime}
$$

式 (33) と式 (34) より, 間隚内の流体圧が $u^{\prime}$ と観 測されるときの全応力 $\sigma$ は, 


\section{表-1 材料の体積圧縮率}

\begin{tabular}{l|r|r}
\hline \multicolumn{1}{c|}{ Material } & \multicolumn{2}{|c}{$\begin{array}{c}\text { Compressibility } \\
\left(\mathrm{cm}^{2} / \mathrm{kg}\right) \times 10^{-6}\end{array}$} \\
\cline { 2 - 3 } & \multicolumn{1}{c}{$C_{b}$} & \multicolumn{1}{c}{$C_{s}$} \\
\hline Quartzinic sand stone & 5.8 & 2.7 \\
\hline Quincy granite (100 ft deep) & 7.5 & 1.9 \\
\hline Vermont marble & 17.5 & 1.9 \\
\hline Concrete (approx. value) & 20 & 2.5 \\
\hline Sedimentary Rock* (porous tuff) & $110-680$ & - \\
\hline Dense sand & 1800 & 2.7 \\
\hline Loose sand & 9000 & 2.7 \\
\hline London Clay (over-consolidation) & 7500 & 2.0 \\
\hline Gasport Clay (normally-consolidation) & 60000 & 2.0 \\
\hline$C_{1}$ (compressibilty of water) $=48 \times 10^{-6}\left(\mathrm{~cm}^{2} / \mathrm{kg}\right)$ & \\
Table 1 (after Skempton, ${ }^{5}{ }^{*}$ after Akai et al. ${ }^{18)}$ & \\
\hline
\end{tabular}

$$
\sigma=n u^{\prime}+\frac{(1-n) c_{b}-c_{s}+c_{l} n}{c_{b}-c_{s}} u^{\prime}
$$

となる. 式（35）の意味するところは，間隚水圧が $u^{\prime}$ と観測されるとき，土が平衡を保つには，。は式 (35) で与えられねばならないということであって，このとき の変形は, 圧力 $u^{\prime}$ の流体に拘束されている. 式 (35) の結果として，有効応力は次式で与えられる.

$$
\begin{aligned}
& \sigma^{e}=\sigma-m u^{\prime} \\
& m=n+\frac{(1-n) c_{b}-c_{s}+c_{l} n}{c_{b}-c_{s}}
\end{aligned}
$$

一般的には，

$$
\sigma_{i j}{ }^{e}=\left(\frac{1}{3} \sigma_{K K}-m u^{\prime}\right) \delta_{i j}+s_{i j}
$$

$\left(\sigma_{i j}{ }^{e}\right.$ : 有効応カテンソル, $s_{i j}$ : 偏差応カテンソ ル)

$c_{s}=0$ とおくと,

$$
\sigma^{e}=\sigma-\left(1+\frac{c_{l}}{c_{b}}\right) u^{\prime}
$$

となり,さらに $c_{l} / c_{b}=0$ の条件下では,

$$
\sigma^{e}=\sigma-u^{\prime}
$$

となって, Terzaghi による古典的結果に一致する.

式（35）を逆にみれば， Bishop の求めた間隚圧係数 のB值が求められる.

$$
\begin{aligned}
& u^{\prime}=\frac{c_{b}-c_{s}}{c_{b}-c_{s}+n\left(c_{l}-c_{s}\right)} \sigma=B \sigma . \\
& B=\frac{c_{b}-c_{s}}{c_{b}-c_{s}+n\left(c_{l}-c_{s}\right)}
\end{aligned}
$$

Bishop $^{13)}$ は式 (42) を求めるために， 非排水状態を 浸水状態と，間隚水圧を一定に保って全応力を増加させ る過程の和であるとして求めている. このような求め方 に対して，本論の方法は間隚水の圧縮性が低いために土 の変形が拘束されているといら物理的考察に基づいてい る.

表一1に Skempton ${ }^{5)}$ にる各種材料の体積圧縮率の

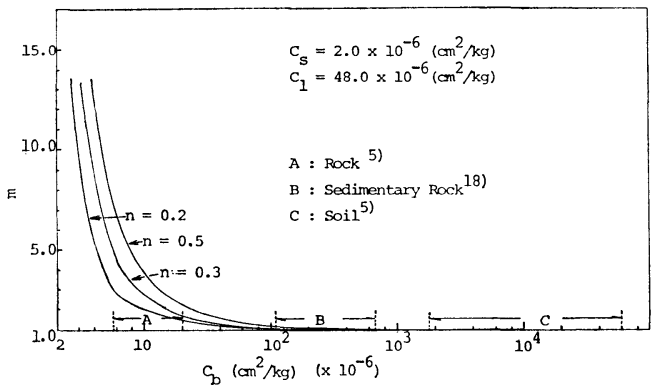

图一3 有効応力パラメーター $\boldsymbol{m}$ と $\boldsymbol{C}_{b}$ との関係 データに, 赤井ら ${ }^{18)}$ による多孔質凝灰岩（大谷石）のデ 一タを加えたものを示す． $c_{l}$ を水の圧縮率とし， $c_{s}$ と $c_{b}$ として正規圧密粘土のデータを式（36）に代入する と, $n=0.5$ として,

$$
\sigma^{e}=\sigma-1.0004 u^{\prime}
$$

となる.ただし， $c_{l}=48 \times 10^{-6}\left(\mathrm{~cm}^{2} / \mathrm{kg}\right)$.

$c_{s}=2.0 \times 10^{-6} \mathrm{~cm}^{2} / \mathrm{kg}$ としたとき， $n$ をパラメーター にして,$m$ と $c_{e} / c_{b}$ の関係をプロットすると, 図一3 が 得られる. 図一 3 より， $c_{b}$ が大きければ，ほとんど $m$ $=1.0$ としてよいが， $c_{b}$ が小さくなってくると， $m$ は 大きくなる.ここで重要なことは，流体の圧縮率が低 く，非排水状態で等方圧が加わったときのひずみ（土粒 子骨格のひずみ）が無視できる場合は， $m=1.0$ として Terzaghi の有効応力を定義することに意味があるが, 間隙流体の圧縮性が大きい場合（たとえば空気の場合） は，ここでいう有効応力を定義する意味がないというこ とである. 式 (24) で $c_{s}=0$ のとき， $c_{l} \rightarrow \infty$ とすると， $\sigma^{(f) \rightarrow 0}$ かつ $\sigma^{(s)} \rightarrow \sigma$ となり, 全応力で解析すればよい. 乾燥砂などはこの場合にあたる. 堆積軟岩である多孔質 凝灰岩（大谷石）では， $n=0.37, c_{s}=2.7 \times 10^{-6} \mathrm{~cm}^{2} /$ $\mathrm{kg}$ として, 表一1 より $m=1.025 \sim 1.156$ となる. こ のときの, 非排水状態で等方圧が作用した場合の体積ひ ずみ $\varepsilon_{K K^{(s)}}{ }^{(s)}$ は，測定された間隙水圧 $u^{\prime}$ を $10 \sim 30 \mathrm{~kg} /$ $\mathrm{cm}^{2}$ とすると, $\varepsilon_{K K^{(s)}}=1.975 \sim 5.925 \times 10^{-4}$ 程度であ る. ただし， $c_{b}=160 \times 10^{-6} \mathrm{~cm}^{2} / \mathrm{kg}$ とした. つまり, 本 論で定義した有効応力式から，この材料では，非排水変 形に使われる等方圧は， $u^{\prime}$ の約 1.1 倍ということにな る $\left(c_{b}=160 \times 10^{-6} \mathrm{~cm}^{2} / \mathrm{kg}\right.$ の場合).この場合, 非排水変 形を無視すれば，他の変形を起こす応力は， $\sigma^{e}=\sigma-1.1$ $u^{\prime}$ となっている. このように，本論で述べた方法を使 えば，どのような変形にどのような応力が対応している かということが合理的に明らかとなる. 図一1 の密な砂 の場合, $n=0.3$ とすると, $\varepsilon_{K K^{(s)}}=1.63 \times 10^{-5} u^{\prime}$ の関 係がある.このとき， $m$ はほとんど 1.0 に近いため, $\sigma^{e}=\sigma-u^{\prime}$ となる.

砂や粘土に比べて, 軟岩では, 式（36）を使った場合 と, Terzaghi の有効応力式を使用した場合を比較して, 
等方的に働く有効応力の算出にかなりの違いがでてくる ことになる. 2. で述べてきたことから，Terzaghi の有 効応力を解釈すれば, 有効応力式 (Terzaghi) が成立す るのは, 全応力から有効応力（式 (36) によって) を差 し引いた応力による等方的非排水圧縮変形が無視でき, かつ $m=1.0$ が近似的に成立する場合であると結論でき る.

\section{3. 古典的な有効応力の解釈との比較}

Skempton $^{5)}$ は Terzaghi の有効応力は近似であり， 真の有効応力ではないと考え, 有効応力の一般化を試み た. Skempton は次の 3 つの定義について調べている.

(I ) $\sigma^{e}=\sigma-\left(1-a_{c}\right) u^{\prime}$

$$
\sigma^{e}: \text { 有効応力 }
$$

$a_{c}:$ 粒子接触面積

$u^{\prime}:$ 間隚水圧

(II) $\sigma^{e}=\sigma-u^{\prime}$

(III) $\sigma^{e}=\sigma-\left(1-a_{c} \tan \psi / \tan \phi^{\prime}\right) u^{\prime}$ （せん断 強度に対して)

$\sigma^{e}=\sigma-\left(1-c_{s} / c\right) u^{\prime}$ （体積変化に対して）

\section{$\phi^{\prime}:$ 土のせん断抵抗角}

\section{$\psi$ : 土粒子自身のせん断抵抗角 \\ $c:$ 土の圧縮率 \\ $c_{s}:$ 土粒子自身の圧縮率}

Skempton は（I ）（III）の定義について，（III）が 最も有効であり，(II) は（III）の近似として, 土に対し てのみ有効であるが，（I）は土の挙動を表現するもの ではないと結論している．しかしながら，（III）の定義 は次のような欠点を有している.

（a）せん断強度に対する定義と圧縮性に対する定義 とが異なっている.

（b）式（45）を導く際に，接触応力（粒子の）と外 力の関係を明らかにするために導入された種々のパ ラメーターは明確な物理的基礎をもっていない.

（c）式（45）を導く際に, Coulomb の強度方程式 を先験的に認めている.

（d）式（46）の誘導において，間隚流体の圧縮性が 考慮されていない.

(c)については, Mitchell19) がすでに指摘してお り，圧縮とせん断に対して同じ形の有効応力式でなけれ ば，土の構成式の変数として意味がない，本論において は，間隙流体と土粒子骨格との相互作用は，体積変化に ついてのみ存在すると仮定しているため, せん断変形, 体積変化ともに, 式 (36) で有効応力を定義している. Skempton は, 式（46）を導くために，体積変化を（非
排水状態での) 次式で表した.

$$
\begin{aligned}
& -\Delta V / V=c(\Delta \sigma-\Delta u)+c_{s} \Delta u \\
& -\Delta V / V: \text { 体積変化 } \\
& \Delta \sigma: \text { 全応力の増分 } \\
& \Delta u: \text { 間隙水圧の増分 } \\
& \text { 式 } \\
& \text { (47) を次のように変形する. }
\end{aligned}
$$

$$
\begin{aligned}
-\Delta V / V & =c\left\{(\Delta \sigma-\Delta u)+\frac{c_{s}}{c} \Delta u\right\} \\
& =c\left\{\Delta \sigma-\left(1-\frac{c_{s}}{c}\right) \Delta u\right\} \cdots
\end{aligned}
$$

式（48）より, 式（46）が導かれている. ただし, 式 （48）では, 等方圧の変化が粒子構造の変化に対して与 える影響は入っていない，式（48）の意味としては，土 粒子の圧縮性を無視した場合, 体積変形は $(\Delta \sigma-\Delta u)$ に よって生じると仮定していることになり，すでに Terzaghi の有効応力式を前提としている. したがって, 式

（46）は定義として意味をもたない. Skempton は間隚 流体の圧縮性を考慮していないが，実際に，圧密現象に おいて, 間郘水が非圧縮性に近いため変形が 遅 れて生 じ，全応力では解析できない事実を考えれば，有効応力 の定義において間隙流体の圧縮性を考慮しないのは不自 然であり，認めることができない。

Skempton をはじめ, 現在の土質力学の分野でなされ ている有効応力の説明において間隙流体の圧縮性が陽な 形で考虑されていない原因は，有効応力を粒子間応力と してとらえていることにある(12),17).

Biot $^{20)}$ は， 2 相系の非圧縮性材料に流体圧 $u$ が作用 した場合, 流体相に働く応力は, $\sigma_{i j}(f)=\frac{1}{3} n u \delta_{i j} \quad(n$ : 間隚率), 骨格系には, $\sigma_{i j}{ }^{(s)}=\frac{1}{3}(1-n) u_{i j}$ としている が，他の場合にこのような応力の分配が正しいのは，す でに述べたように，土のエレメントを水の中に非被覆で 浸し，水圧をかける場合である，さて，先に述べた応力 の分配が常に成立するとすると, 式（49）となる.

$$
\begin{aligned}
& \sigma_{i j}{ }^{e}=\sigma_{i j}{ }^{(s)}-(1-n) u^{\prime} \delta_{i j} \\
& \sigma_{i j}{ }^{f}=n u^{\prime} \delta_{i j}, \sigma_{i j}=\sigma_{i j}{ }^{(s)}+\sigma_{i j}{ }^{(f)} \\
& \left(\sigma_{i j}{ }^{e}: \text { 有効応力テンソル }\right)
\end{aligned}
$$

式 (49) の $\sigma_{i j}{ }^{e}$ を, 石原 ${ }^{17)}$ は粒子間力を断面積で割 ったものとして説明を試みているが，このような説明 は, 力のつり合いに対する取扱いに偏しており, 粒状性 をモデルにした式 (49) の解釈にすぎない， 2 相系の混 合体理論に粒状性を導入する必要はない. 式 (49) から 得られる結果は, $\frac{1}{3} \sigma_{K} K^{e}=\frac{1}{3} \sigma_{K K}-u^{\prime}$ となり, Terzaghi の定義と一致するが，混合体理論としては積極的 な意味がなく，論理体系としては公理としてとらえる以 外に式 (49) の意味はない21).

粒子間に働くさまざまな粒子間力は，土の構成関係の 
一部である圧縮特性を通して，有効応力にかかわる. し たがって, 変形過程に抢ける土の構造骨格の変化も考虑 に入れねばならない，図一3 から，間隙流体が水の場 合， $m \doteqdot 1.0$ としてよい. 土の圧縮率 $C_{b}$ の範囲はかな り広いために, Terzaghi の有効応力の概念は土に扔い てはほぼ成立するであろう。このように厳密にいえば, 式（49）は式（36）と式（37）で置き換えられるべきで あり，Terzaghi による定義は，式 (36) と式 (37) か ら近似として求められる. 現在行われている有効応力の

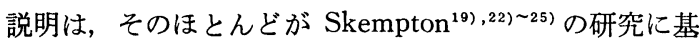
ゔいているため不合理であり，本論の論理と矛盾する.

\section{2. 結論}

本論文の結果を要約すると，以下のようになる.

（1） Terzaghi による有効応力の定義について，飽 和土を 2 相系の材料と考え，応力のつり合いだけでな く, 間隙流体，土粒子の圧縮性および土粒子骨格の圧縮 性の面から再検討を行い有効応力を式 (36) と式 (37) で定義した. その結果, Terzaghi による有効応力式は， 土粒子自身が非圧縮性でかつ，間郘水が非圧縮性の場合 に厳密に成立することが明らかとなった。

（2）本論で有効応力とは，等方的非排水圧縮変形以 外の変形を生じさせる応力である.つまり，通常の土で は, 非排水圧縮変形は, 全体の変形に対して無視するこ とができ, かつ, 式 (36) の $m$ がほとんど 1.0 に等し いため, Terzaghi の式が成立する. したがって，そう でない場合は， Terzaghi の有効応力を使用することが 無意味となり，より一般的理論である混合体理論によっ て土の変形を解析することが必要となる.

最後に，本研究に対して貴重な助言および討議をいた だいた, 赤井浩一京都大学教授, 足立紀尚京都大学防災 研究所助教授, 太田秀樹京都大学助教授, 田村 武京都 大学助手に感謝いたします.

\section{參考文献}

1) Terzaghi, K. : Die Berechnung der Durchlassigkeitsziffer des Tones aus dem Verauf der Hydrodynamichen Spannungserscheinnungen, reprinted in from Theroy to Practice in Soil Mechanics, John Wiley \& Sons., New York, pp. 133 146, 1923.

2) Terzaghi, K. : Theoretical Soil Mechanics, John Wiley \& Sons., New York, pp. 11 15, 1943.

3) Rendulic, L. : Ein Grundgesetz der Tonmechanik und sein experimenteller Beweis, Bauingenieur, 18, pp. 459 467, 1937.

4) Bishop, A.W. : The Principle of Effective Stress, Norwegian Geotechnical Institute, No. 32 , pp. 1 5, 1960.

5) Skempton, A.W. : Effective Stress in Soils, Concrete and Rocks, Conf. Pore Pressure and Suction in Soils, pp. 4 16, 1960.

6) Skempton, A.W. : Significance of Terzaghi's Concept of Effective Stress, from Theory to Practice in Soil Mechanics, John Wiley \& Sons., pp. 42 53, 1960.

7）赤井浩一・田村 武：弾塑性構成式による多次元圧 密の 数値解析, 土木学会論文報告集, 第 269 号, pp. 95 104 1978 年 1 月.

8) Goto, H., F. Oka and K. Kawamoto : Liquefaction of Soil and Dynamic Response of Ground, Proc. of 5th Japan Earthquake Engineering Symposium, pp. 637 $\sim 680,1978$.

9) Oka, F. : Constitutive Theory for Solid-Fluid Mixture and Its Application to Stress Wave Propagation Through Cohesive Soil, Proc. of JSCE, No. 272, pp. 117 130, Apr., 1978.

10) Biot, M.A. : Mechanics of Deformation and Acoustic Propagation in Porous Media, J. Appl. Phys., Vol. 33, pp. 1482 1498, 1962.

11) Ishihara, K. : Propagation of Compressional Waves in a Saturated Soil, Proc. of Int. Symp. of Wave Propagation and Dynamic Properties of Earth Materials, Univ. of New Mexico Press, pp. 195 206, 1968.

12) Bishop, A.W. and G. Eldin : Undrained Triaxial Tests on Saturated Sands and Their significance in the General Theory of Shear Strength, Geotechnique, 2, No. 1, pp. 13 32, 1950.

13) Bishop, A.W. : The influence of an Undrained change in Stress on the Pore Pressure in Porous Media of Low Compressibility, Geotechnique 23, No. 3, pp. 435 442, 1973.

14) Green, A.E. and P.M. Naghdi : A Dynamical Theory of Interacting Continua, Int. J. Eng. Sci., Vol. 3 , pp. 231 241, 1965.

15) Müller, I. : A Thermodynamic Theory of Mixtures of Fluids, Arch. Rational Mech. Anal., Vol. 24, pp. 370 403, 1967.

16) Ishihara, K. : Approximate Forms of Wave Equation for Water-Saturated Porous Materials and Related Dynamic Modulus, Soils \& Foundations, Vol. 10, No. 4, pp. $10 \sim 38,1970$.

17）石原研而：土質動力学の基礎，鹿島出版会，pp. 58 59, 昭和 51 年.

18）赤井浩一・足立紀尚・西 好一：堆積軟岩（多孔質凝灰 岩) の弾塑性挙動, 土木学会論文報告集, 第 271 号, pp. $83 \sim 95$, 昭和 53 年 3 月.

19) Mitchell, J.K. : Fundamentals of Soil Behavior, John Wiley \& Sons., pp. 186 196, 1976.

20) Biot, M.A. : Theory of Elasticity and Consolidation for Porous Anisotropic Solid, J. Applied Physics Vol. 26, No. 2, pp. 182 185, Feb., 1955.

21）岡 二三生・中川加明一郎：混合体理論よりみた有効応 力概念について, 第 32 回土木学会年次学術構演 会 講 演 集, III-64, pp. 114 115, 昭和 52 年.

22) Scott, R.F. : Principle of Soil Mechanics, AddisonWiesly Pub. Company Inc., pp. 163 166, 1963.

23) Lambe, T.W. and R.V. Whitman : Soil Mechanics, John Wiley \& Sons., pp. 241 250, 1969.

24）山口柏樹: 土の力学, エンジニアリングサイエンス講座, 共立出版, pp. $7 \sim 9,1976$.

25）最上武雄編：土質力学, 技報堂, pp. 480 483, 1969.

(1979.3.22 - 受付) 